\title{
ISLAM AND MULTICULTURAL THEOLOGY
}

\author{
Muhaemin Latif \\ Fakultas Ushuluddin dan Filsafat UIN Alauddin Makassar \\ muhaemin.latif@uin-alauddin.ac.id
}

\begin{abstract}
This article discusses the relationship between Islam and multicultural theology. It employs qualitative research methodology with focusing on library research in getting documents relating to the issue. Islam and multicultural theology are two important disciplines that need to be reconsidered to capture the dimensions of similarities for both of them. Although multicultural theology is originally coined in the history of western countries like America and European countries and it is more likely concerned with Christian theology, it does not mean that Islam and multicultural theology have no relevant connection. The author comes to conclude that these issues are strongly related in the theoretical framework as well as in practical. Issues such as respect, recognition, and tolerance are crucially important for both of them. Islam itself makes those aspects the fundamental philosophy in social interaction, particularly, love and humanism are the key elements of Islam. The last mentioned are not seriously taken into account in multicultural theology which is a more formal or legal relationship.
\end{abstract}

Keywords: Islam; Multicultural; Theology; Tolerance; Love

\section{INTRODUCTION}

Islam and multicultural theology are two important themes that are interesting to discuss in the current context, especially in reducing the crisis of tolerance that often occurs in relations between religious adherents. Multicultural theology itself is a terminology that wants to place theology as the philosophical basis of multiculturalism. Theology in this context is not only science that talks about the concept of divinity as well as the meaning of theology itself. But theology also focuses on the realities of society, especially regarding social injustice and discrimination in cultural relations. Multicultural theology is a type of theology whose role is urgent in the context of today's society, especially in reorganizing one's religious relations with others.

If classical theology still dwells on the metaphysics of divinity and does not seem to care about the human context, ${ }^{1}$ then multicultural theology which is an important part of modern theology will make human relations its focal point. In line with the theologies that have developed in modern life, such as liberation theology, social theology, development theology, agrarian theology, and so on, all of which speak of injustice in various aspects, multicultural theology also talks about the same thing although in different contexts.

Multicultural theology in this context is like a foundation in applying the ideas of multiculturalism, especially those related to tolerance, recognition, and equality of rights and services without distinguishing one culture from another. Multicultural theology will place equality as the basis in formulating cultural relations between ethnic groups, races, and languages. These aspects become patrons in multicultural theology which in turn can

\footnotetext{
${ }^{1}$ Muhaemin Latif, Teologi Pembebasan dalam Islam (Jakarta: Orbit Publishing, 2017), p. 121.
} 
strengthen the national spirit regardless of ethnic, racial, and religious differences. Multicultural theology is not only a foundation in religion but theology is expected to be a legitimating tool for multiculturalism as an ideology that needs attention for theologians and all who care about the spirit of nationalism. The foundation of this multicultural theology cannot be separated from the spirit of humanism which is the heart of the national and religious defense.

Although the popularity of multicultural theology is still inferior to multiculturalism, multicultural education, multiethnic education, ethnic studies, its contribution in managing diversity between one culture and another cannot be denied. Concerning national life today in Indonesia, it seems that the presence of multicultural theology is highly expected to be the antidote for religious groups who feel that they are the owners of the truth. Several cases that have occurred in recent months, such as the suicide bombing at the Makassar Cathedral church, indicate that there are still serious problems related to religion. ${ }^{2}$ Therefore, the presence of this multicultural theology is so important amid today's increasingly uncertain religious atmosphere. Multicultural theology in this case does not only oversee and observe cultural relations, but also religious relations as part of its focal point.

However, references related to this theme are still minimal. As far as the author searches, from several authoritative references related to multicultural theology, the author only finds one book entitled multicultural theology where the concern is Christian theology. Generally speaking, multicultural theology can be easily found in various journals. However, the discussion domain is more directed to Christian theology.

In this context, the author in this case tries to connect Islamic theology and multiculturalism and tries to find the philosophical foundation of multiculturalism in Islamic theological literature. Likewise, the author will track the theological arguments related to multiculturalism, both those originating from the Qur'an and those explained by the traditions of the Prophet Muhammad. Certainly not an easy job to build a strong relationship between the two. Because on the one hand, theology is a discipline that discusses divinity, especially in the perspective of the Christian tradition, while multiculturalism is understood as a process or effort to build equality and equal treatment and equal equality between one culture and another in various moments.

However, despite departing from different perspectives, theology and multiculturalism are not impossible to unite. Both have the same philosophical foundation, namely how to strengthen human relations.

\section{RESEARCH METHODOLOGY}

This paper is qualitative research. I focus on library research to gain data or information relating to the issue. The author concern with two main resources, including multicultural theology and the Islamic aspect especially from Quranic exegesis. All these data were contrasted and compared to capture comprehensive information considering that both Islam and multiculturalism emerged in a different context. Islam comes from the east, Arab, whereas multicultural theology strongly associates with Christian theology or western countries. In this sense, the author carefully selects data from different resources to avoid misunderstanding regarding the main issue.

2 https://nasional.kompas.com/read/2021/03/29/06283821/fakta-fakta-di-balik-peristiwa-bombunuh-diri-di-makassar?page=all 


\section{III.DISCUSSION AND FINDINGS}

\section{A. Defining Multicultural Theology}

As explained above, multicultural theology is not as popular as multiculturalism, multicultural education, or multiculturalism politics. However, the author underlines that several important points must be paid attention to about multicultural theology, such as the harmony between theology and multiculturalism, the willingness to accept differences and diversity, the creation of justice, and the absence of discrimination between religious adherents and between internal religious groups. So simply, multicultural theology can be defined as a theology that oversees the diversity of religions and cultures which is a necessity in human life as a condition for creating an atmosphere of togetherness and equality.

Multicultural theology focuses on religious diversity where culture is an important part of religion itself. Religion is, in some ways, practiced in tandem with the rituals of the culture itself. This argument then underlies Clifford Geertz who says that religion for the Javanese is not much different from culture itself. ${ }^{3}$ Perhaps this is what underlies that Javanese tradition is a religion itself which is then called Javanese religion. ${ }^{4}$ Religious rituals are indeed related to cultural rituals, this condition does not only occur in Javanese tradition, in several places in the archipelago it is emphasized that cultural practices often represent religious rituals themselves. So, connecting theology with culture, which was later known as multicultural theology, could be a bridge for gluing cultural ties where religious elements are involved.

As the material for strengthening the meaning of multicultural theology, it is better to listen to the understanding of multicultural theology described by a professor of religious studies, Abdul Aziz Sachedina.

"Multicultural theology is a theology that demonstrates its attention and concern for global citizens, and influences these aspects of life far beyond geographical boundaries, let alone ethnic and ethnic boundaries." 5

The above understanding illustrates that multicultural theology is based on humanism. He did not want to be trapped by differences in ethnicity, religion, and race. For multicultural theology, the foundation of the relationship is humanity. This relationship can increase awareness among human beings. Related to this, the author is reminded of the statement of the philosopher Plato:

\section{"I am not an Athenian, nor a Greek, but I am a citizen of the world"}

Plato's statement above may not be very relevant at that time, but the human journey in this life confirms that the statement finds its relevance. Plato does not want to be stuck with ethnic, religious, and racial identities, he wants to become a global human being which indicates that everywhere humans are the same in nature. This similarity factor makes Plato want to serve based on humanity, not on these pseudo identities. Moreover, the current frictions between nations, which are also spiced up with elements of religion, ethnicity, and race, make these frictions even stronger which eventually

${ }^{3}$ Clifford Geertz, Michael Banton, Religion as a Cultural System (USA: Tavistock, 1966), p.121.

${ }^{4}$ Clifford Geertz, The Religion of Java (USA: University of Chicago Press, 1976), p.235.

5 Abdul Azis Sachedina, The Islamic Roots of Democratic Pluralism (USA: Oxford University Press, 2001), p.342. 
results in conflict or clash as predicted by Samuel Huntington, the clash of civilizations (clash of civilizations). ${ }^{6}$

As mentioned earlier, theology following its genealogy has the nuances of a Christian tradition that is more dominant than Islam. ${ }^{7}$ So the author in this case tries to refer to a Christian scholar, G. Sudarmanto. He said that multicultural theology was built on five important foundations, namely relational, social, operational, moral, and transformational. ${ }^{8}$ The relation is the main foundation with the consideration that the focus of multicultural theology is harmonious relations between human beings as a strong form of expression to God. When referring to the perspective of Islamic theology, this point is presented by strengthening vertical relationships (to God) and horizontal relationships (to humans). This relationship is often referred to as hablun minallahi wa hablun minannas. ${ }^{9}$

The relational foundation above has a strong correlation with the second aspect, namely social. This is intended to strengthen the foundation for Christians to counter social problems, especially conflicts based on ethnic and religious differences. On the consideration of humans as social beings, this social aspect places humans as an important part of other humans.

In other words, no human being in this life is capable of living alone. Every human being needs another human being to fulfill his life needs. This foundation is not only framed in a theoretical framework but must be grounded in the praxis of human life. It is this argument that underlies the "operational" foundation as an important part of multicultural theology. The essence of operations in this context is that multicultural theology can be useful in practical human life. That is, this theology is practical operational in answering real problems in the reality of life, especially the problem of religiosity between followers of different religions.

Multicultural theology is not only placed as a discourse or scientific discourse that does not touch the grass-root layer. This theology shines in the public spaces of human life, filling the gaps that often occur in the interactions of life both on a global and regional scale. In this case, multicultural theology is not part of the religious problem, but it is a solution to these various problems. In other words, its presence is an alternative solution in strengthening religious defenses so that there is no conflict between religious adherents. Simply put, multicultural theology is part of the resolution of religious conflicts in Indonesia. ${ }^{10}$

If multicultural theology is placed as a material in conflict resolution, the target is the operational activities of human life. This activity does not necessarily pass on the same understanding to build harmony or harmony. That is, this human activity requires control so as not to be trapped in the puddle of imbalance between religious adherents to claim to be the sole owner of truth. At this point, the moral aspect can be a guardian for

${ }^{6}$ Samuel P. Huntington, The Clash of Civilizations and The Remaking of World Order (USA: Simon \& Schuster, 1996), p. 211.

${ }^{7}$ Muhaemin Latif, Perkembangan Teologi Modern (Makassar: Alauddin University Press, 2020), p. 2.

${ }^{8}$ G. Sudarmanto, Teologi Multikultural (Batu: Bidang Literatur Departemen Multimedia YPPII Batu, 2014), p.132.

${ }^{9}$ Lihat QS Ali- Imran 2/112.

${ }^{10}$ Tri Astutik Haryati, “Teologi Multikultural: Resolusi Konflik Religiusitas di Indonesia” Religia, 14(2), 2011, p. 146-168. 
Christians in interpreting multicultural theology. Moral in their view cannot be separated from the role and function of religion as an ethical guide in human life. The ultimate goal of all these principles or foundations is that multicultural theology must bring about changes which in multicultural education are called class action (social action) that requires social change. This is what G. Sudarmanto meant as "transformational". ${ }^{11}$ In leadership theory, this transformative model is the most sought after for leading an organization, even a country. The transformative nature in which there is change makes this typical leadership the dream of every member or citizen. This narrative of change is the expectation of multicultural theology which in turn can carry out social change, especially to erode ethnic, religious, and racial barriers that make people polarized in building social interactions.

If we look further, the above aspects are not only the domain of Christian tradition, but Islamic theology also has the same principle. For example, the moral aspect which is the second basis, in Islamic theology, this point becomes a priority scale in the lives of Muslims, even the Prophet Muhammad. sent into this life to perfect morals or morals. This emphasis on the moral aspect is evidenced by the many arguments that come from the scriptures and from the traditions of the Prophet (this point will be discussed in the following description).

Likewise in the social, operational, and transformational aspects, all of which can be shown in various arguments that further strengthen that the five principles above are universal. In other words, that all religions have multicultural principles because the source of religion itself comes from one God, although it is symbolized by different names. By Frithoup Schuon, that religion is different from an exoteric (technical) point of view, but from an esoteric point of view, humans have points in common, all of which lead to the one God, namely Allah swt.

So, if the understanding of multicultural theology is simplified above, at least the five foundations above can be the basis for the development of multicultural theology. In other words, multicultural theology is the integration of the five principles above which not only strengthens the relationship between humans and their God, but also strengthens relationships between human beings, regardless of differences, religion, ethnicity, race, and even language. That to achieve closeness to God, human relations both in terms of religion, culture, politics, and economics must be the main concern of multicultural theology. Recognition of the absolute difference in various aspects is a fundamental point in this theology.

According to the author, the above principles and philosophies are taught in every religion, including Islam and Christianity. Indeed, in the reality of life, there are internal groups in religion who make the relationship to God their only goal in life, while negating human relations. They assume that the reality of humanity is not correlated with its relationship with God. This view often leads certain groups to generate hatred against other groups which in turn creates conflicts between followers of religion, culture, ethnicity, and race. For them, the right group is only them, so there is no need to create harmonious relations with other groups.

In addition, the view that the only way to God is to improve relations with Him is also often an argument for this group to launch attacks of resistance or hatred against others. This philosophy is certainly contrary to multicultural theology which places all groups in the same position on an equal basis. In multicultural theology, the term "them"

${ }^{11}$ G. Sudarmanto, Teologi Multikultural, p. 35 
(the others), to designate other groups can be a stumbling block to create togetherness by making the term "we" replace "them". The separation of these two terms philosophically has made humans polarized which becomes the embryo of an imbalance in terms of position and role in a community or nation. This condition in turn creates social injustice and discrimination.

The phenomenon above is a challenge for every believer, regardless of any religion. In other words, this condition does not only belong to adherents of Islam, but the attitude of feeling self-righteous and assuming that other groups are wrong and even claimed to be heretical is a phenomenon of religious adherents in general. This is where the main task of multicultural theology is how to place the acknowledgment of the existence of religion, ethnicity, and ethnicity as the main priority in its discussion.

To respond to the above phenomenon, it is interesting to take a sample of a group of young Evangelicals ${ }^{12}$ in the United States who initiated a movement that voiced the importance of putting social justice as an important theme in the Bible. This movement departs from the anxiety of young Evangelicals who view the (old) Evangelical fundamentalist group as having no sense of care regarding the importance of creating social justice for fellow human beings.

The facts above can be seen from the absence of the older generations of Evangelicals against taking sides with minority groups, such as black or Hispanic groups. Although this movement has not been carried out massively in the United States, at least, the attitude of concern has emerged in the youth of the Evangelical sect to bring social justice among the children of the United States. This concern is also shown in the various writings of young Evangelicals that relate Evangelical theology to social justice. They specifically focus on the holiness of God concerning the reality of humanity. It becomes problematic, when the holiness of God is only symbolized by a relationship to the same God, it is equally complicated to place social justice as the main issue. The complexity of the term social justice cannot be separated from the complexity of the meaning of social justice itself where every element of a culture or religious group in Americans has its perspective on this terminology. ${ }^{13}$

In the Islamic tradition, concern for the urgency of bringing social justice to various aspects of human life is also voiced in various countries. For example, in India, a leading theologian as well as a social activist, Asghar Ali Engineer, voiced the need for liberation from the oppression perpetrated by one group of Muslims, the Bohras Shiites who are a fraction of the Ismaili Shiites. ${ }^{14}$ This voice of liberation rose in the public spaces of India which invites concern for fellow followers. One of the insistences and demands of the Shia Bohras group is to provide social justice for all the Shia followers. ${ }^{15}$

However, in its development, the urge or demand to create a climate or atmosphere of internal alignment among the followers of Bohras developed in a broader

12 This Evangelical group is one of the groups in the Protestant Christian tradition which in quantity has a high population in the United States. More than a quarter of the American population is from the Evangelist group which is also divided into several groups such as Baptists, Mennonites, Methodists, Holiness, Pentecostals, and so on. They believe that humans will in principle experience reincarnation (born again) by receiving salvation from God.

13 Peter T Cha, "Doing Theology in a Multicultural Theological Community" Torch Trinity Journal, 10(1). 2007, p. 95-106.

${ }^{14}$ Asghar Ali Engineer, The Bohras (New Delhi: Vikas Publishing, 1980), p. 167.

${ }^{15}$ Muhaemin Latif, Teologi Pembebasan, p. 40. 
direction. This demand in turn penetrates theological, ethnic, cultural boundaries, which leads to siding with humanity. This movement was later called the liberation theology movement where the intellectual actor was Asghar Ali Engineer. He wrote specifically the theology of liberation which was viewed from an Islamic perspective as a form of response to classical Islamic theology which, according to him, was still trapped in the normative aspect. He said that classical Islamic theology is still busy with the romantic theological debates between theologians which are completely unrelated to the reality of human life. Islamic theology does not only discuss the themes of monotheism, debates about the word of God, the attributes and substance of God, but Islamic theology makes real problems faced by humans as important themes in its theology. Themes such as poverty, social conflicts, agrarian conflicts, environmental degradation, clashes between religious adherents, and injustice and discrimination of cultural groups, should ideally be a serious concern of Islamic theology. ${ }^{16}$

The emergence of liberation theology itself did not come from the womb of Islam. His birth was first associated with a social movement pioneered by social activists in Latin America around the 1970s who experienced poverty due to the power structure that was not in their favor. The activists demanded that churchmen fight for the fate of millions of Latin American citizens, especially their civil rights, not become tools of legitimizing power or a state that has no concern for structurally poor citizens. According to these social activists, the churchmen have harmed the sacred mission of the church to liberate its congregations from various forms of oppression. ${ }^{17}$

Related to multicultural theology, the author views that liberation theology is like a big umbrella for types of theology, including multicultural theology. This statement is supported by the same vision and mission between liberation theology and multicultural theology. If liberation theology has a vision of human liberation in all forms of the hegemony of power, then multicultural theology focuses on the formation of a reform movement of relations between one culture and another, between one religious adherent and another, to realize liberation from the hegemony of one culture with another or group domination. certain religions over others. The estuary of all this is the creation of equality and equality in social interactions regardless of religious, racial, and cultural differences.

As a form of strengthening the meaning of multicultural theology, the author will explore the historical roots of multicultural theology traced from Islamic history, especially the period of the Prophet Muhammad and his companions. In addition, the author also tries to explore important aspects of multiculturalism which are enshrined in the holy book al-Qur'an as the main reference in Islam as illustrated in the following description.

${ }^{16}$ Asghar Ali Engineer, Islam, and Liberation of Theology: Essays on Liberal Elements in Islam (New Delhi: Sterling Publishers Limited, 1990), p. 112.

${ }^{17}$ Gustavo Gutierres, Theology of Liberation: History, Politics, and Salvation (Maryknoll: Orbit Books, 1973),p. 198. 


\section{B. Islam and Multicultural Theology}

Multicultural theology as explained earlier that this term is synonymous with Christian tradition. However, the values that exist in multicultural theology can also be found in Islamic teachings. Values such as active tolerance, recognition of differences, accepting diversity as a necessity, grounding social justice, making humanity the foundation of teachings, have become important principles in Islamic teachings. In other words, the values of multicultural theology have strong relevance to Islamic theology.

\section{Social Justice and humanity}

If we trace the birth of Islam since it first appeared in the Arab region, then several values of multicultural theology can be learned. For example, the idea of social justice is one of the fundamental values in multicultural theology. This idea was crucial in early Islamic history. It is known that the Arab society before the arrival of Islam was feudal and oligarchic, especially in their trading and business system. ${ }^{18}$ Mecca, which was the center of trade at that time, tended to be controlled by certain tribes, which made other tribes excluded from global trade flows.

In other words, in the structure of the Meccan Arab society, there are social classes that polarize Arab society based on these classes. These social classes are based on ethnic considerations which have implications for the unequal distribution of business opportunities. Call it the Quraysh tribe through the Abd Shams route which controlled the economy at that time, while the Quraysh tribe with the Hasyim route did not become an important part of the trade-economic cycle. The second path is where the Prophet Muhammad saw. born. ${ }^{19}$ So, there was a trade monopoly controlled by certain tribes in the context of Arab society at that time.

Even though the Prophet Muhammad was a merchant, but the Prophet's tribal cluster in principle did not come from the big traders among the Quraysh tribe. The Prophet himself traded only to help his uncle, Abu Talib, and became an employee of a business owned by a rich widow, Khadijah bint Khuwailid who later became his wife. In other words, the Prophet was not a capitalist like the Arab "capitalists" at that time. In this context, the prophet was not part of the trade monopoly run by the Quraysh from the Abd Shams line above.

According to the author, the consequences of a trade monopoly can in turn create social injustice in Arab society. The economic wheel only revolves around certain tribes while other tribes only become spectators of the economic cycle. This injustice has implications for the widening gap between rich Arabs and poor Arabs. This condition is the embryo of social injustice that occurs within Arab society.

The presence of Islam in this context is at least an alternative solution to erode economic injustice that leads to social injustice. Islam comes with egalitarian principles that do not discriminate between one tribe and another. An individual is seen from his level of piety, not because of his ethnicity or race. And one of the indicators of piety is when an individual can be fair to fellow human beings.

As a form of Islamic response to this condition, these issues of injustice have become a major concern and concern for the verses that were revealed in Mecca, as explained in QS al-Nahl/16: 90 which reads:

${ }^{18}$ Philip K. Hitti, History of the Arabs: From the Earliest Times to the Present (New York: Palgrave Macmillan, 2002), p. 139.

${ }^{19}$ Philip K. Hitti, The History of the Arabs, p. 140. 
The translation:

"Verily, Allah commands (you) to do justice and do good, to give help to relatives, and He forbids (to do) abominable acts, evil deeds, and enmity. He teaches you so that you can take lessons."

The verse above explains that the command to do justice and do good is a direct instruction from Allah swt. Although this verse was revealed in Mecca and targeted Meccan traders, the context of the verse can be relevant today. This justice is a fundamental aspect of human life because, with the presence of justice both in legal, social, and economic aspects, humans are protected from conflicts in cultural, religious, and racial relations. In other words, the conflict or clash arises if the relationship is built on injustice. About multicultural theology, humans as cultural beings must put justice as a fundamental basis in building cultural relations between one another.

Asgar Ali Engineer said that the justice referred to in the Qur'an is generalization and equality. ${ }^{20}$ These two meanings can be understood in a wider context, for example in the context of cultural relations, the principles of generalization and equality are essential. However, justice in the Qur'an must be comprehensive, and cannot be particular. Justice is not only limited to one dimension but must be placed in a multidimensional perspective. In other words, in creating justice, various aspects must be integrated, such as economic, social, cultural, and even political aspects. To create social justice as the core of multicultural theology, economic justice must be a concern. Likewise, political justice must also depart from social and economic justice. All these aspects must work simultaneously and synergize with each other.

Another verse that must also be considered in multicultural theology is QS. alNisa/4: 135 .

"O you who believe, be true enforcers of justice, be witnesses for Allah even if it is against yourself or your mother, father, and relatives. If he is rich or poor, then Allah knows best his benefit. So do not follow your lust because you want to deviate from the truth. And if you twist (words) or refuse to be witnesses, then surely Allah is Knowing of all that you do."

In line with the previous verse, the verse above was also revealed in Mecca as a response to various injustices that occurred in Mecca. The verse is not only an order to do justice but to be an enforcer of justice. This means that justice must be formed from the top (top-down) because to create justice, the system must run well. The orientation of justice itself according to the verse above is the benefit for all parties regardless of their status and position. That is, the benefit never harms one group while another group benefits.

Another factor that causes this injustice is ego ${ }^{21}$ excessive that may arise from individuals or groups. In the terminology of the verse above is excessive lust or arrogance. The desire to dominate a group with various interests and the desire to hegemony a certain culture is an example of the cause of injustice which in turn leads to chaos or no benefit. Creating a just multicultural theology must be supported by a willingness and willingness to accept others. This last point that hit the Arab community at that time before the birth

${ }^{20}$ Muhaemin Latif, Teologi Pembebasan, p. 175.

${ }^{21}$ The term ego was adopted by the western philosopher, Sigmund Freud. He said that humans psychologically have three levels, the id, ego, and superego. 
of Islam, how they were not willing to the existing differences, even tended to want to dominate the different tribes.

In the tradition of Arab society, tribal egoism is an undeniable character in his life. They were proud of the existence of their tribe and even tended to exaggerate it above others while considering other tribes did not have an important role in Arab society at that time. The contestation of tribal egoism is often shown in the poetry memorization competition which they hold regularly. One of the important themes in the context of these verses is the height of their tribes. The height of the tribe is indicated by the various poems they perform. The pride of this tribe is also shown by the spirit to win the war between tribes. The consequences of this inter-tribal battle gave birth to a superior spirit for the tribes that often won wars and made the tribes that could not compete in war inferior. The losing party will be eliminated from life, including in the economic arena. Meanwhile, the tribe that always wins will play economic roles and in turn hegemony other tribes. $^{22}$

The contestation above will also give birth to tribal arrogance that claims to have advantages over others. This tribal arrogance factor is a barrier to the formation of multicultural education. Tribes or cultures that feel superior have difficulty accepting inferior cultures because of their unbalanced assumptions or assumptions. This cultural superiority also shapes the service and treatment that is lame between one culture and another.

In the context of the history of Islamic civilization, the domination and hegemony of certain tribes in the end also became one of the reasons for rejecting the Prophet Muhammad. because they hope that the born prophet comes from their tribe, not from the clan or tribe of the Prophet Muhammad. This character became a stumbling block for Islam at that time, which wanted to instill the principles of equality, justice for all, not for the interests of certain parties. Islam itself came to greet all without discriminating against others, even the Prophet Muhammad. himself sent to the universe ${ }^{23}$, not just a particular tribe or clan as described in the QS. al-Anbiya/21: 107 which reads

Translate: I did not send you (Muhammad saw.) But as a mercy for the whole world.

\section{Love and Affection}

Love and compassion are also important elements in multicultural theology. Referring to the previous verse that the Prophet Muhammad saw. is a symbol of love and a representation of grace for all beings who are not limited by the various cultures that exist on this earth. Its presence on this expanse of earth transcends geographical and sociological boundaries. In other words, Prophet Muhammad saw. not only belongs to Muslims but all creatures in this cosmos. Therein lies the significance of the meaning of grace in this verse. This term means love or affection. This means that the Prophet Muhammad is not only owned by humans but is a representation of love and a symbol of affection for this universe.

The presence of the Prophet Muhammad has become a symbol of love that can be the glue of relations between one culture and another. The human bond that transcends

${ }^{22}$ Philip K. Hitti, History of the Arabs, p. 131.

${ }^{23}$ The Universe is the realm of the cosmos that exists not only on earth but also on everything that exists outside of planet earth, beings in the solar system, stars, comets, and so on. The essence of the universe is defined the same as nature which is all that exists other than Allah swt. 
cultural boundaries is not only based on the symbiotic factor of mutualism (mutual benefit) between cultures as well as the literal meaning of multiculturalism. But the important point of this mercy is the relationship or relationship without any strings attached, in the language of Islamic theology is sincerity itself. This means that intercultural relations are not pragmatic but transcend various social, political, and economic interests.

According to the author, the point of love and affection is strength in multicultural theology, especially in the perspective of Islamic theology. This power escapes multicultural education or is not even mentioned in multiculturalism in general. Multicultural education focuses more on aspects of materialism, such as the school environment, government support, school facilities and infrastructure, curriculum, and so on. Meanwhile, aspects of non-materialism, such as bonds of love, caring attitudes among others, affection between them, are not raised in the educational process. ${ }^{24}$

Consequently, the relationships that are built are physical-material relationships that do not touch the deepest layers of human psychology, namely feelings and love. This last aspect can be strong ammunition to strengthen the relationship because it can penetrate only formal-mechanistic boundaries. Love or feelings of belonging to each other are genuine, not artificial. If love underlies human relations, then the relationship can be ascertained to be genuine, not based on the factor of reward and punishment. However, growing this love in social groups is not an easy job. It takes a long and gradual educational process to create a climate of human relations based on love.

In contrast to the relationship between nations in the current context, that love has disappeared, replaced by a desire to dominate others under the pretext of economic, cultural, and even religious control. These elements are often the actors behind the drama of conflict, both between countries and between cultures. This love relationship is indeed increasingly difficult to find in the reality of human life. However, what deserves attention for the theology of multiculturalism is the concept of peace-loving which is the core of Islamic teachings. The history of Islamic civilization is undeniably full of wars, even the prophet himself led the war several times. It is recorded that the Prophet Muhammad led the war nine times. This quantity does not indicate that Islam likes war as some orientalists claim. They allege that the expansion of Islam is synonymous with the sword or violence. Whereas in the history of war at the time of the prophet, it shows that the war is defensive in nature. That is, the love of peace is the hallmark of Islam at the time of the Prophet Muhammad. War is the last alternative after all negotiations and dialogues end in a deadlock.

The war that occurred during the Prophet's war was also not based on hatred of fellow humans, but rather on the arrogance of the Quraysh tribe who culturally hated the Prophet Muhammad and his followers. In other words, what is being fought is the arrogance and egoism of the tribe because this factor breeds hatred between human beings. In this context, the event of the conquest of Mecca known as the Mecca fathu can also represent that Islam is a religion of peace-loving. This incident did not take any casualties, even though by force, the Islamic troops could easily kill the Quraysh infidels who still harbored hatred in their hearts for the Muslims. ${ }^{25}$ However, the troops of the Prophet Muhammad. Instead, he taught peace in the war by asking all Quraysh infidels

\footnotetext{
${ }^{24}$ James A Banks, "Pluralism and Educational Concept" Pluralism and Educational Concepts: A Clarification" Peabody Journal of Education 54 (2), p. 73-78

${ }^{25}$ Philip K. Hitti, The History of the Arabs, p. 139.
} 
who wanted protection to enter the house of Abu Sufyan, who incidentally was an enemy of the Prophet. This event is like the culmination or plenary of the war carried out by the Prophet by prioritizing love and peace.

So, if traced the key to the success of the Prophet Muhammad's da'wah. for approximately twenty-three years is the love of peace. The Prophet did not bring hatred to his people at all, even to his enemies even though the prophet was often hurt and even planned to be killed. The factor of love for his people is adopted in the context of multicultural theology as a form of implementation of love for fellow human beings. The Prophet's love for his people far exceeds his love for himself. Once again, according to the author's search, this aspect of love is absent in multicultural education, let alone what is practiced in the Western world as described previously.

\section{Class Action}

In addition to the factors of love and feelings that underlie these cultural relations, the struggle to change the social order which is then called class action in the perspective of multicultural education also needs attention. ${ }^{26}$ The struggle of oppressed social classes due to racism in the 1960s, especially in America, as explained in the previous discussion, also underlies the birth of multiculturalism. With the same concept, this struggle has long been fought by Islam itself about 15 centuries ago. The Prophet Muhammad's resistance to the domination and hegemony of the Quraish tribe was not only related to the liberation of the polytheistic or dynamic concept of divinity, but the struggle was the struggle of social classes, resistance to feudalistic economic attitudes, and resistance to patriarchal culture represented by Arab society before the advent of Islam. He not only voiced liberation from various forms of hegemony, the Prophet Muhammad saw. himself is actively involved in liberating various forms of injustice and discrimination in culture, social, political, and economic. Even not infrequently, the prophet became a victim of this injustice. ${ }^{27}$

What was done by the Prophet Muhammad above is in principle a class action lawsuit. This class lawsuit is a fundamental effect of multicultural education. ${ }^{28}$ Moreover, the lawsuit initiated by this prophet against the domination and treatment of the hegemonic Arab community was led directly by him. He sued the system of Arab society by raising collective awareness that there is no difference between one culture and another. Everything must be treated fairly without any privilege to other tribes. This collective awareness is also an important element in multiculturalism as an ideology. This awareness is also the driving force for the emergence of class action lawsuits arising from a long educational process, especially in the context of multicultural education.

The prophet's class-action lawsuit is a form of protest against the existing social order, and more importantly the attitude of the Arab community's faith which is in a dilemma. This means that Arab society is not only socially classed, but the god they believe in is also class. The position of their god in society has a different status and position. These god classes make up their pluralistic beliefs. ${ }^{29}$ The presence of Islam in

${ }^{26}$ James A. Banks, "Human Rights, Diversity and Citizenship Education” The Educational Forum 73: 100, p. 100-109.

${ }^{27}$ Asghar Ali Engineer, Islam and Liberation Theology, p. 35.

${ }^{28}$ James A. Banks, "The Construction and Historical Development of Multicultural Education, 1962-2012" Theory into practice, 52. (2), p. 345.

${ }^{29}$ Philip K. Hitti, The History of the Arabs, p.123. 
this context challenges these classes of gods by presenting the monotheistic face of the Islamic God. The plurality of human beings itself is recognized by Islam, while the plurality of gods is a polytheism. Believing that there is a power other than god is a real form of polytheism. This is the keyword in QS. al-Hujurat/49: 13 as follows:

"O mankind! Lo! We have created you from a male and a female and made you into nations and tribes that ye may know one another. Lo! The noblest of you in the sight of Allah is the most pious of you. Indeed, Allah is All-Knowing, AllAware." (Surat al-Hujurat: 13)

The above verse places that human beings genealogically did depart from diversity and difference. This fact is a fact of life that must be accepted by all human beings. So forcing all human beings into one race or one nation is a dream that will never come true as desired by the philosophy of Plato mentioned earlier. Humans are beings framed by differences be it a nation, race, tribe, culture, and even religion.

So, according to the author, the above verse confirms the existence of a plural life or plural society is an undeniable destiny in human life. It's just that the human task in the context of these differences is to know each other. The command to get to know each other in the verse proves that human beings should not develop hatred between one culture and another. This is where the important meaning of this multicultural theology is, how these differences become a strong social capital to get to know each other. It is not that these differences are exacerbated to give birth to hatred between cultures. ${ }^{30}$ At this point, it is interesting to quote QS. Ali Imran/3:63 which reads:

"Translation: Say (Muhammad), "O People of the Book (Jews and Christians), let us (hold) on the same sentence, there is no difference between us and you. We should not worship other than Allah and should not take some of us as gods besides Allah. If they turn away, say, (Muhammad and the believers) to them, 'We are the surrendered ones."

The verse above illustrates that differences are commonplace and imperative in human life, both in the context of culture and religion. History has documented this fact with the presence of various religions which were also brought by different prophets. These religions are still guided by groups of people with different cultures and races. However, the message of the verse also concludes that these differences should not be put forward, but the principles of equality must be put forward. This is the meaning of verse taalau ilaa kalimatin sawaa (hold fast to the same page). ${ }^{31}$ This is where there is a strong correlation between the understanding of Islamic theology and multiculturalism which prioritizes equality by managing existing differences.

As a form of response sentence, sawaa is the concept of recognition itself. Through getting to know each other, the principles of equality will be a guide in building interactions. However, this cross-cultural introduction must be framed with theological values, such as the belief that the form of introduction between one human being and another is a concrete example of siding with humanity. This last point in turn further increases the devotion to Allah swt. as it is written in the verse above, that the noblest among humans is the pious person.

\footnotetext{
${ }^{30}$ Sukidi, Teologi Inklusif Cak Nur (Kompas: Media Nusantara, 2001), p. 56.

${ }^{31}$ Nurcholish Madjid, Islam Kemodernan dan Keindonesiaan (Bandung: Mizan, 1987), p. 165.
} 
The above aspect of piety is missing in the context of secular multicultural education because it has organized the relationship to divinity. The relationship to God is considered not the domain of multicultural education, the area is the realm of religion that is not related to education. This separation certainly cannot be separated from the concept of a secular state that separates religion and the state in its government. Religion for them is a personal matter that is not correlated with the state, while the state also cannot intervene in religious matters. This is the hallmark of western countries. So multicultural theology in the context of the Christian tradition, in this case, the west, are the roles played by the church as a system independent of the state. ${ }^{32}$

Multicultural theology in this context does not equate cultural relations with God's relations, because this cannot be equated. His philosophy is based on understanding and acceptance of other cultures as God's sacred message to humans so that humans are not hegemonic and dominate others. In the perspective of liberation theology, the goal of building human relations is to create a classless society or later called a classless society. This point is also one of the objects of multicultural education which eliminates social classes in the world of education so that there is a balance in service. According to Asghar Ali Engineer, this classless society, by multicultural theology, is based on human declarations and testimonies that only God is Almighty, Allahu Akbar. Humans are equal before God. In other words, there are no social classes or castes in society. Only God is Great, while humans are equal before God. ${ }^{33}$

The Islamic struggle in asserting a classless society is also evidenced by the liberation of my slaves who socially belong to an employer. At the beginning of the advent of Islam in Arab lands, the tradition of slave ownership was still a fully Arab tradition, especially those known as the capitalists of Arab society. This tradition is not purely from the Arabs, because historically, civilizations before Islam, also had slaves. In the context of Arab society, having a slave is a pride in itself because it is a symbol of wealth. In addition, having slaves can also increase their influence and class in society. When Islam came, many of my slaves were later freed and converted to Islam. One of the examples of my slaves who are very popular until now is the companion of the Prophet Muhammad saw, Bilal bin Rabah. Bilal was the first slave to convert to Islam who was later freed by Abu Bakr as-Shiddiq after receiving cruel punishment from his employer for converting to Islam. ${ }^{34}$

Bilal himself is a symbol of resistance to the various cruelties of the Quraysh infidels. Even though he was tortured by his employer, he never budged from his belief as a devout early Muslim. Bilal was never afraid to fight the oppression and injustice he got. Even the Prophet himself placed him in an honorable place as the only muezzin (caller to prayer) of the prophet, as well as the first muezzin in the history of Islam. This position is quite prestigious for a Bilal who culturally does not come from a respectable tribe, even he comes from black Abessinia (now Ehtiopia). However, the prophet never looked at a person based on his ethnicity, race, or skin color. ${ }^{35}$ For the author, the prophet is a perfect example of a true multicultural leader in the history of human civilization.

32 Peter T Cha, "Doing Theology in a Multicultural Theological Community", p. 95-106.

${ }^{33}$ Asghar Ali Engineer, Theology of Liberation, p. 67.

${ }^{34}$ Asghar Ali Engineer, Islam dan Pembebasan (Yogyakarta: LKiS,1993), p.87.

${ }^{35}$ Asghar Ali Engineer, Islam dan Pembebasan, p. 87. 
The gradual abolition of slave slaves until there is a total abolition by Islam is a sign of Islam's siding with a classless society. At this point, the phenomenon can also be interpreted that Islam views humans as being on the same level, not distinguished from their social classes. In other words, there is no concept of human segregation in the context of Islamic teachings. Islam emphasizes this aspect in various verses in the Qur'an, where Allah swt. glorify humans as in QS. al-Isra/17:70 which reads:

"And verily We have honored the children of Adam, We carried them on land and in the sea, We gave them sustenance from the good things and We gave them a perfect advantage over most of the creatures We have created."

\section{Glorifying Human Beings}

Placing humans as noble beings is an important requirement in elaborating multicultural theology. When fellow humans glorify each other, then an attitude of tolerance in intercultural relations will be created. The conflict or hostility is present if both parties do not glorify each other's descendants of Adam. Therefore, the verse above is relevant to be cited as an important foundation in strengthening multicultural theology. The philosophy of nobility among Adam's descendants adds to the strong emotional bonds between the different nations.

The verse above explains that humans essentially come from one source, namely the Prophet Adam. Compared to other creatures on this earth, humans have special rights compared to others. This glory is a privilege given directly by God. If God alone as the creator glorifies humans, then it is an ironic attitude if there is a human being who then places humans in a position that is not noble. In other words, demeaning other humans is the same as humiliating oneself because genealogically they come from the same source. The differences in race, skin color, as well as ethnicity, and culture are just a color of the journey of human civilization. These differences cannot be a justification for blaming each other between one tribe and another. This is an important point of multicultural theology which is often negated its role and function in human life

With multicultural education, the concept of glorifying human beings also escapes the material of multicultural education. According to the author, multicultural theology also emphasizes the importance of glorifying humans without any differences in service. Glorifying means placing human dignity as the initial foundation in elaborating the values of multiculturalism such as tolerance, mutual respect, and so on. Glorifying humans cannot be based on an excessive ethnocentric attitude. In Islam, honoring humans is very important to be implemented in real life regardless of one's ethnicity and nation. Even the Prophet Muhammad. himself ever received a direct warning from Allah swt. when he ignores one of his blind guests ${ }^{36}$ when the Prophet held a meeting with the leaders of Quraish such as Abu Jahl, Utbah bin Rabiah, and Walid bin Mughirah. This event is immortalized in the Qur' an in the QS. Abasa/80: 1-10 as follows:

"Translate: He (Muhammad) was sour-faced and turned away. Because a blind man came to him."

God's rebuke to the prophet above proves that this condition can happen to anyone, including the Prophet Muhammad saw. especially to his people. Concerning multicultural theology, the above verse calls on every human being to respect human

36 The guest was popularly known as Abdullah bin Abi Maktum who wanted to learn Islam from the Prophet Muhammad saw. 
beings in any situation, especially those who are physically handicapped, such as the blind who in the present context are called disabled. The disabled group is now concerned with multiculturalism education or inclusion education. The rebuke to the prophet above is in principle directed to all human beings to glorify human beings regardless of their condition, human beings must still be glorified as God glorifies them. This is where the significance of the theological meaning of multiculturalism is compared to multicultural education. This argument also in turn underlines that killing a human being for no apparent reason is a great sin because it has exceeded God's authority.

If this concept of dignity becomes fundamental in multicultural education, then cultural clashes will not be a common phenomenon in modern society, or at least can be reduced. This human glory is because God has created it in the best form, even the best form of creation is human. That is more or less the meaning of QS at-Tin/95: 4. However, human beings sometimes do not glorify themselves by enslaving themselves to materialism. Because of their enslavement to physical things, human beings easily destroy the values of humanity. Even sometimes due to the pragmatic motivation of materialism, its respect for human beings is only pseudo, not genuine. He glorifies other human beings when he needs it, but when he does not need it, then his honor vanishes. Examples of this type of relationship usually occur in structural relationships. If the glory of man depends on the extent to which he humanizes other people, then, on the contrary, the lowest human being when he humiliates others. In this regard, it is interesting to note the statement of the late Gus Dur as follows:

\section{"Glorifying man means glorifying his creator, while humiliating man means humiliating his creator" 37}

The point of the late Gus Dur's statement above implies that the defense is humanoriented, not defending God but hurting or degrading human dignity. This argument also underlies Gus Dur's writing of an article entitled "God does not need to be defended" which later became the title of a book is a collection of his writings published in Tempo magazine in the 1970s-1990s. ${ }^{38}$ The title of this book is also inseparable from the phenomenon of Indonesian people who persistently fight for the defense of God, stand in the front row when demonstrations occur, but often demean the dignity of other people who do not agree with him. Gus Dur in this context does not mean that he does not agree that God is not defended, but that it must be accompanied by respect for human dignity.

It's just that in the context of secular multicultural education, respect for humanity is only based on the spirit of humanism which the Western world has known as the "new religion". It is important to know that the basis of the Western world's foothold in doing good or respecting humanity is not based on religious impulses or spirituality born of religion, but the sensitivity factor of humanism. Humanism has become one of the characteristics of modern western thought, where humans have the freedom to develop their scientific reasoning regardless of religious control. The history of the emergence of the renaissance (revival of the Western world) also begins with the humanism movement in Italy. In other words, the concept of glorifying humans has long emerged in the Western world which is then called humanism. However, humanism in this context is more secular in nature, where the role and function of theology do not become an integral part of the

\footnotetext{
${ }^{37}$ https://twitter.com/nu_online/status/761106487867387905

${ }^{38}$ Abdurrahman Wahid, Tuhan tidak perlu dibela (Yogyakarta: Noktah - LKiS, 2017).
} 
humanism movement. In other words, that the motivation of modern Western society in doing good, including to humans, is pure because of the basis of humanity. ${ }^{39}$

This is where the role of multicultural theology that tries to "Islamises humanism" where the foundation of human dignity is not only motivated by love for humans, but theological motivation also plays an important role. This framework is important to straighten out the understanding of secular multicultural education that glorifies humans not by simply "serving" humans, while its historical roots are related to uprooted religion. Multicultural education in the context of the western world assumes that tracing the origins of humans, whether they come from Adam or not, is not important to them. Glorifying humans for them doesn't have to deal with proving that humans all came from Adam or something else. This understanding will in turn come to whether the man was created by God or it is due to the natural process of natural laws operating in this universe. According to the author, western multicultural education does not pay much attention to this context, let alone puts the divine dimension in the context of humanity.

Allowing humanism to work alone in the context of multicultural education without involving theological elements will give birth to various variants of relations to the Creator. For example, understanding naturalism as a variant that believes that nature works following applicable natural laws. God is not involved in the process of organizing this nature which is so neat. Although in the context of naturalism, they believe that God is not an important part of this nature. Concerning multicultural theology, humans, who are then referred to as small natures (microcosms) can create their circumstances without the intervention of religion or God. Simply put, humans can realize multicultural education without being backed up with theological elements as the vision of multicultural theology. Glorifying humans in this context need not wait for theological legitimacy. This understanding of naturalism itself is one of the doors to the flow of atheism, a flow that can simply be interpreted as an understanding that does not believe in God. ${ }^{40}$

The understanding of naturalism above reminds the writer of muktazilah theology which in the history of Islamic theology is known as rational theology. This theology believes that humans can be maximally empowered by their rationality. Human reasoning can determine good and bad deeds even without the help of religion or theology, including multicultural education. ${ }^{41}$ The role of revelation in this school is to justify and strengthen what humans do concerning good deeds. Associated with glorifying humans, humans with their rationality can know it is important to glorify them. However, knowing that glorifying humans is obligatory for humans, then the role of revelation should not be denied. A revelation that explains that glorifying Adam's children and grandchildren is an absolute obligation that must be carried out by humans. This is where the relevance to the theology of multiculturalism makes the values of secular multiculturalism receive theological enlightenment, especially in the context of the origin of Adam's creation as the first human. Multicultural theology wants to emphasize that glorifying humans as an important entity must be based on theological values. For example, how the argument to glorify humans is based on the glorification of the descendants of Adam by God as the creator.

\footnotetext{
${ }^{39}$ Muhaemin Latif, Perkembangan Teologi Modern, p. 15
${ }^{40}$ Muhaemin Latif, Perkembangan Teologi Modern, p. 41.
${ }^{41}$ Harun Nasution, Teologi Islam: Aliran Aliran Sejarah Analisa Perbandingan (Jakarta: UI Press,
2009), p. 121.

${ }^{39}$ Muhaemin Latif, Perkembangan Teologi Modern, p. 15
${ }^{40}$ Muhaemin Latif, Perkembangan Teologi Modern, p. 41.
${ }^{41}$ Harun Nasution, Teologi Islam: Aliran Aliran Sejarah Analisa Perbandingan (Jakarta: UI Press,
2009), p. 121.

${ }^{39}$ Muhaemin Latif, Perkembangan Teologi Modern, p. 15
${ }^{40}$ Muhaemin Latif, Perkembangan Teologi Modern, p. 41.
${ }^{41}$ Harun Nasution, Teologi Islam: Aliran Aliran Sejarah Analisa Perbandingan (Jakarta: UI Press,
2009), p. 121.

${ }^{39}$ Muhaemin Latif, Perkembangan Teologi Modern, p. 15
${ }^{40}$ Muhaemin Latif, Perkembangan Teologi Modern, p. 41.
${ }^{41}$ Harun Nasution, Teologi Islam: Aliran Aliran Sejarah Analisa Perbandingan (Jakarta: UI Press,
2009), p. 121.
} 


\section{IV.CONCLUSION}

Islam and multicultural theology have a close relationship both from a theoretical perspective and in a practical context. Islam, which emerged amid Arab society, puts humans in their real place regardless of differences in physical or social status. There is no difference between Arabs and non-Arabs. Their degree and status are seen in terms of their piety. Meanwhile, the emergence of multicultural theology cannot be separated from the protests and demands of the American and European people regarding their status and position. These demands are related to equal rights and equal services in the economy, education, and culture. The common thread between the two can be concluded that what is the main mission of multicultural theology has become a grand vision of the presence of Islam on this earth. Social justice, love, and compassion among others, honoring humans are some of the goals of human life taught in the Qur'an and the Prophet Muhammad. This vision is also the goal of the struggle of multicultural theology.

\section{REFERENCES}

Banks, James A. "Human Rights, Diversity and Citizenship Education" The Educational Forum 73: 100.

Banks, James A. "Pluralism and Educational Concept" Pluralism and Educational Concepts: A Clarification" Peabody Journal of Education 54 (2).

Banks, James A. "The Construction and Historical Development of Multicultural Education, 1962-2012" Theory into practice, 52. (2).

Cha, Peter T. "Doing Theology in a Multicultural Theological Community" Torch Trinity Journal, 10(1). 2007.

Engineer, Asghar Ali. Islam and Liberation of Theology: Essays on Liberal Elements in Islam. New Delhi: Sterling Publishers Limited, 1990.

Engineer, Asghar Ali. Islam dan Pembebasan. Yogyakarta: LKiS,1993.

Engineer, Asghar Ali. The Bohras. New Delhi: Vikas Publishing, 1980.

Geertz, Clifford. Michael Banton, Religion as a Cultural System. USA: Tavistock, 1966.

Geertz, Clifford. The Religion of Java. USA: University of Chicago Press, 1976.

Gutierres, Gustavo. Theology of Liberation: History, Politics, and Salvation. Maryknoll: Orbit Books, 1973.

Haryati, Tri Astutik. "Teologi Multikultural: Resolusi Konflik Religiusitas di Indonesia" Religia, 14(2), 2011.

Hitti, Philip K. History of the Arabs: From the Earliest Times to the Present. New York: Palgrave Macmillan, 2002. 
https://nasional.kompas.com/read/2021/03/29/06283821/fakta-fakta-di-balik-peristiwabom-bunuh-diri-di-makassar?page $=$ all

https://twitter.com/nu_online/status/761106487867387905

Huntington, Samuel P. The Clash of Civilizations and The Remaking of World Order. USA: Simon \& Schuster, 1996.

Latif, Muhaemin. Perkembangan Teologi Modern. Makassar: Alauddin University Press, 2020.

Latif, Muhaemin. Teologi Pembebasan dalam Islam. Jakarta: Orbit Publishing, 2017.

Madjid, Nurcholish. Islam Kemodernan dan Keindonesiaan. Bandung: Mizan, 1987.

Nasution, Harun. Teologi Islam: Aliran Aliran Sejarah Analisa Perbandingan. Jakarta: UI Press, 2009.

Sachedina, Abdul Azis. The Islamic Roots of Democratic Pluralism. USA: Oxford University Press, 2001.

Sudarmanto, G. Teologi Multikultural. Batu: Bidang Literatur Departemen Multimedia YPPII Batu, 2014.

Sukidi, Teologi Inklusif Cak Nur. Kompas: Media Nusantara, 2001.

Wahid, Abdurrahman. Tuhan tidak perlu dibela. Yogyakarta: Noktah - LKiS, 2017. 